\title{
Efficacy of Two Licensed Avian Influenza H5 Vaccines Against Challenge with a 2015 U.S. H5N2 clade 2.3.4.4 Highly Pathogenic Avian Influenza Virus in Domestic Ducks
}

\author{
Mary J. Pantin-Jackwood, ${ }^{\mathrm{AD}}$ Eric DeJesus, ${ }^{\mathrm{B}}$ Mar Costa-Hurtado, ${ }^{\mathrm{C}}$ Diane Smith, ${ }^{\mathrm{A}}$ Klaudia Chrzastek, ${ }^{\mathrm{A}}$ Darrell R. Kapczynski, ${ }^{\mathrm{A}}$ \\ and David L. Suarez ${ }^{\mathrm{A}}$

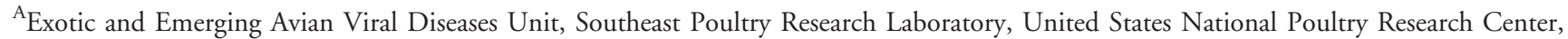
Agricultural Research Service, United States Department of Agriculture, 934 College Station Road, Athens, GA 30605

${ }^{\mathrm{C}}$ Institut de Recerca i Tecnologia Agroalimentàries (IRTA) and the Universitat Autònoma de Barcelona (UAB), Centre de Recerca en Sanitat Animal, Campus de la Universitat Autònoma de Barcelona, Barcelona, Bellaterra 08193, Spain
\end{abstract} \\ ${ }^{B}$ Eastern Laboratory, United States Department of Agriculture, Food Safety and Inspection Service, 950 College Station Road, Athens, GA 30605
}

Received 10 May 2018; Accepted 3 August 2018; Published ahead of print 6 August 2018

SUMMARY. Highly pathogenic avian influenza (HPAI) clade 2.3.4.4 viruses from the H5 goose/Guangdong lineage caused a major outbreak in poultry in the United States in 2015. Although the outbreak was controlled, vaccines were considered as an alternative control method, and new vaccines were approved and purchased by the U.S. Department of Agriculture National Veterinary Stockpile for emergency use. In this study, we evaluated the efficacy of two of these vaccines in protecting Pekin ducks (Anas platyrhynchos var. domestica) against challenge with a H5N2 HPAI poultry isolate. A recombinant alphavirus-based vaccine and an inactivated adjuvanted reverse genetics vaccine, both expressing the hemagglutinin gene of a U.S. H5 clade 2.3.4.4 isolate (A/Gyrfalcon/Washington/41088-6/2014 H5N8), were used to immunize the ducks. The vaccines were given either as single vaccination at 2 days of age or in a prime-boost strategy at 2 and 15 days of age. At 32 days of age, all ducks were challenged with A/turkey/Minnesota/12582/15 H5N2 HPAI virus clade 2.3.4.4. All ducks from the nonvaccinated challenge control group became infected and shed virus; one duck in this group presented mild ataxia, and a second duck died. No mortality or clinical signs were observed in vaccinated and challenged ducks, with the exception of one duck presenting with mild ataxia. Both vaccines, regardless of the vaccination strategy used, were immunogenic in ducks and reduced or prevented virus shedding after challenge. In conclusion, good protection against $\mathrm{H} 5 \mathrm{Nx}$ infection was achieved in ducks vaccinated with the vaccines examined, which were homologous to the challenge virus, with prime-boost strategies conferring the best protection against infection.

RESUMEN. Eficacia de dos vacunas con licencia contra influenza aviar H5 frente a un desafío con un virus de la influenza aviar altamente patógeno H5N2 en patos domésticos de los Estados Unidos del año 2015 y del clado 2015 2.3.4.4.

Los virus de la influenza aviar altamente patógena (HPAI) 2.3.4.4 del linaje H5 ganso/Guangdong causaron un brote importante en la avicultura de los Estados Unidos en el año 2015. Aunque el brote fue controlado, las vacunas se consideraron un método de control alternativo y nuevas vacunas fueron aprobadas y adquiridas por la Reserva Nacional Veterinaria del Departamento de Agricultura de los Estados Unidos para uso en caso de emergencia. En este estudio, se evaluó la eficacia de dos de estas vacunas en la protección de patos Pekin frente al desafío con un aislamiento aviar H5N2 de alta patogenicidad. Se utilizaron una vacuna recombinante basada en alfavirus y una vacuna generada por genética inversa, inactivada y con adyuvante, ambas expresando el gene de la hemaglutinina de un aislamiento H5 clado 2.3.4.4 (A/Gyrfalcon/Washington/41088-6/2014 H5N8), para inmunizar los patos. Las vacunas se administraron como vacunación única a los 2 días de edad o con un programa de primovacunación y refuerzo a los 2 y 15 días de edad. A los 32 días de edad, todos los patos fueron desafiados con el virus de alta patogenicidad A/turkey/Minnesota/12582/15 H5N2 clado 2.3.4.4. Todos los patos del grupo control no vacunado y desafiado se infectaron y excretaron al virus; un pato en este grupo presentó ataxia leve y un segundo pato murió. No se observó mortalidad o signos clínicos en patos vacunados y desafiados, con la excepción de un pato que presentó ataxia leve. Ambas vacunas, independientemente de la estrategia de vacunación utilizada, fueron inmunogénicas en patos y redujeron o evitaron la diseminación del virus después del desafio. En conclusión, se logró una buena protección contra la infección por $\mathrm{H} 5 \mathrm{~N} 2$ en los patos vacunados con las vacunas evaluadas, las cuales eran homólogas al virus de desafio y las estrategias de primovacunación y refuerzo confirieron la mejor protección contra la infección.

Key words: Highly pathogenic avian influenza, H5, clade 2.3.4.4, ducks, vaccines, vaccination

Abbreviations: $\mathrm{A}=$ alphavirus; $\mathrm{AIV}=$ avian influenza virus; ANOVA = analysis of variance; $\mathrm{CL}=\mathrm{cloacal} ; \mathrm{dpc}=\mathrm{days}$ postchallenge; $\mathrm{ECE}=$ embryonating chicken eggs; $\mathrm{EID}_{50}=50 \%$ egg infective dose; ELISA = enzyme-linked immunosorbent assay; Gs/GD = A/goose/Guangdong/1/1996; GyrF/14 = A/Gyrfalcon/Washington/41088-6/2014 H5N8; HA = hemagglutinin; HAU $=$ hemagglutinin units; $\mathrm{HI}=$ hemagglutination inhibition; $\mathrm{HPAI}=$ highly pathogenic avian influenza; $\mathrm{I}=$ inactivated; OP $=$ oropharyngeal; qRTT-PCR = Real time quantitative reverse transcription polymerase chain reaction; RNA = ribonucleic acid; SPF $=$ specific pathogen free; Tk/15=A/turkey/Minnesota/12582/2015 H5N2; USDA=U.S. Department of Agriculture; USNPRC $=$ U.S. National Poultry Research Center

The H5N1 A/goose/Guangdong/1/1996 (Gs/GD) lineage of highly pathogenic avian influenza (HPAI) virus continues to spread across the world, affecting wild birds, poultry, and humans. Despite efforts to control these viruses, they continue to evolve, leading to

\footnotetext{
${ }^{\mathrm{D}}$ Corresponding author. E-mail: Mary.Pantin-Jackwood@ars.usda.gov
}

the emergence of multiple sublineages and the generation of reassortant $\mathrm{H} 5$ strains with novel gene constellations, including H5N2, H5N5, H5N6, and H5N8 subtypes. In late autumn 2014 , H5N8 HPAI viruses were detected in Siberia, several countries in Europe, in South Korea, and in Japan (8,32). Concurrently, this virus was detected in the United States (3). In addition, another 
Table 1. Vaccination strategy in ducks. Ducklings were divided into groups ( $n=10$ per group) and vaccinated with a recombinant alphavirusbased replicon vaccine (A vaccine) or an adjuvanted inactivated reverse genetics vaccine (I vaccine) by using a single or prime-boost strategy. At 32 days of age, ducks were challenged with A/turkey/Minnesota/12582/15 H5N2 HPAI virus and monitored daily for clinical signs.

\begin{tabular}{|c|c|c|c|c|c|}
\hline \multirow[b]{2}{*}{ Experimental groups } & \multirow[b]{2}{*}{ Treatment } & \multicolumn{4}{|c|}{ Age (days) } \\
\hline & & 2 & 15 & 32 & 42 \\
\hline 1 & Nonvaccinated, nonchallenged & - & - & Serology & Serology \\
\hline 3 & Vaccinated (A vaccine) & A vaccine & - & Serology and virus challenge & Serology \\
\hline 4 & Vaccinated (I vaccine) & I vaccine & - & Serology and virus challenge & Serology \\
\hline 5 & Vaccinated $(\mathrm{A}+\mathrm{A}$ vaccine $)$ & A vaccine & A vaccine & Serology and virus challenge & Serology \\
\hline
\end{tabular}

novel reassortant H5 HPAI clade 2.3.4.4 virus (H5N2) was identified as the cause of an outbreak in poultry in Canada during November 2014 (16) and later detected in the United States in wild waterfowl, raptors, and backyard poultry, including domestic waterfowl (29). From March to June 2015, this H5N2 virus predominated in the United States, with extensive interfarm transmission occurring in the midwestern region (27). The magnitude of the H5N2 HPAI outbreak and the associated risk of reintroduction of the virus in commercial poultry by migratory wild birds led to the inclusion of several licensed vaccines that were likely protective against clade 2.3.4.4 $\mathrm{H} 5 \mathrm{~N} 2$ as part of U.S. National Veterinary Stockpile $(7,25)$. These vaccines included an inactivated reverse genetics $\mathrm{H} 5 \mathrm{~N} 1$ vaccine and a recombinant alphavirus-based replicon vaccine, both expressing the U.S. H5N8 index virus (A/ gyrfalcon/Washington/2014 H5N8) hemagglutinin (HA) gene modified to have a low pathogenic avian influenza cleavage site. The main difference between the alphavirus-based replicon vaccine and other viral vectored vaccines is that the alphavirus is replication restricted because it does not contain all the genes necessary for viral packaging. Therefore, the vaccine has characteristics of a live vaccine in that it induces humoral and cell-mediated immunity, but it has the safety of an inactivated vaccine, so for regulatory purposes, it is considered an inactivated vaccine $(9,30)$.

Domestic ducks are a small but important sector of the poultry industry affected by the H5Nx HPAI outbreaks (22). Domestic ducks are also common backyard poultry frequently in contact with wild waterfowl, thus serving as a possible bridge between avian influenza virus (AIV)-infected wild birds and other poultry species. Consequently, reducing the risk of virus infection in domestic ducks is considered crucial for controlling the spread of $\mathrm{H} 5 \mathrm{Nx}$ Gs/GD lineage viruses. Vaccination can reduce viral shedding among infected birds and thereby decrease transmission rates, which is especially important when implementation of enhanced biocontainment measures is impractical (26).

In a previous study, we showed that Gs/GD lineage H5N2 and H5N8 HPAI viruses can easily infect domestic waterfowl and transmit to contact birds (15). The disease is mostly asymptomatic, but infected ducks shed virus for several days, representing a risk to other poultry species. The majority of the vaccines used in domestic ducks to protect against Gs/GD lineage H5N1 HPAI viruses have been oil emulsion inactivated vaccines. The seed strains for these types of vaccines can be naturally occurring low pathogenic avian influenza strains, but because of antigenic drift, seed strains are more likely to be viruses made by using reverse genetics techniques that change the HPAI virus to be low pathogenic. Both commercially available and experimental vaccines have been evaluated in ducks
(14). However, there is insufficient information on the effectiveness of $\mathrm{H} 5 \mathrm{HPAI}$ vaccination against the more recent $\mathrm{H} 5 \mathrm{Nx}$ viruses in domestic duck species to help guide disease control programs.

The objective of this study was to examine the efficacy in domestic ducks of two vaccines licensed in the United States for their potential in controlling $\mathrm{H} 5 \mathrm{Nx}$ clade 2.3.4.4 HPAI viruses in poultry. A commercial $\mathrm{H} 5$ vector vaccine based on RNA replicon system, which uses an alphavirus backbone to express the $\mathrm{H} 5$ gene from a HA clade 2.2.3.4 H5N8 HPAI virus, and an inactivated $\mathrm{H} 5$ vaccine also based on the same HA were used to determine protection of Pekin ducks (Anas platyrhynchos var. domestica) from challenge with a H5N2 HPAI virus from the 2015 U.S. outbreak.

\section{MATERIALS AND METHODS}

Vaccines and challenge virus. The $\mathrm{H} 5 \mathrm{~N} 1$ seed strain was produced by reverse genetics technology that included a HA gene from clade 2.3.4.4, A/Gyrfalcon/Washington/41088-6/2014 H5N8 (GyrF/14) that had a modified cleavage site compatible with a low pathogenic AIV. The NA (N1 subtype) and internal genes were from an egg-adapted A/ Puerto Rico/08/1934 (H1N1) strain, and the rescued virus was shown to be low pathogenic (5). Virus stock was prepared in specific-pathogenfree (SPF) embryonating chicken eggs (ECE), followed by inactivation with betapropiolactone and diluted to provide a concentration of 512 hemagglutinin units (HAU) per $0.2 \mathrm{ml}$ when mixed (70/30) with Montanide ISA VG70 oil emulsion adjuvant (SEPPIC Inc., Fairfield, NJ) according to the manufacturers' recommendations. The recombinant alphavirus replicon-based vaccine (SirraVax, Harrisvaccines, Inc., Ames, IA, conditionally approved by the U.S. Department of Agriculture [USDA)]) (31) also carries the modified HA gene from $\mathrm{GyrF} / 14$.

The HPAI A/turkey/Minnesota/12582/2015 H5N2 (Tk/15) clade 2.3.4.4 virus, obtained from the virus repository at Southeast Poultry Research Laboratory, USDA-Agricultural Research Service (Athens, GA) was used as the challenge virus. Virus stock was amplified in SPF ECE, and virus titer was determined by $50 \%$ egg infective dose $\left(\mathrm{EID}_{50}\right)$. The experiment was performed in biosecurity level 3-enhanced facilities in accordance with procedures approved by the U.S. National Poultry Research Center (USNPRC) Institutional Biosecurity Committee.

Experimental design. Newly hatched Pekin ducks (A. platyrhynchos var. domestica) were obtained from a commercial hatchery. Serum samples were collected from 15 ducks to ascertain that the birds were serologically negative for antibodies to the nucleoprotein of influenza A viruses, as determined by the commercial competitive ELISA test FlockCheck AI (IDEXX Laboratories, Westbrook, ME). At 2 days of age, ducks were randomly divided into seven groups of 10 ducks each (Table 1). Group 1 served as nonvaccinated nonchallenged controls. 

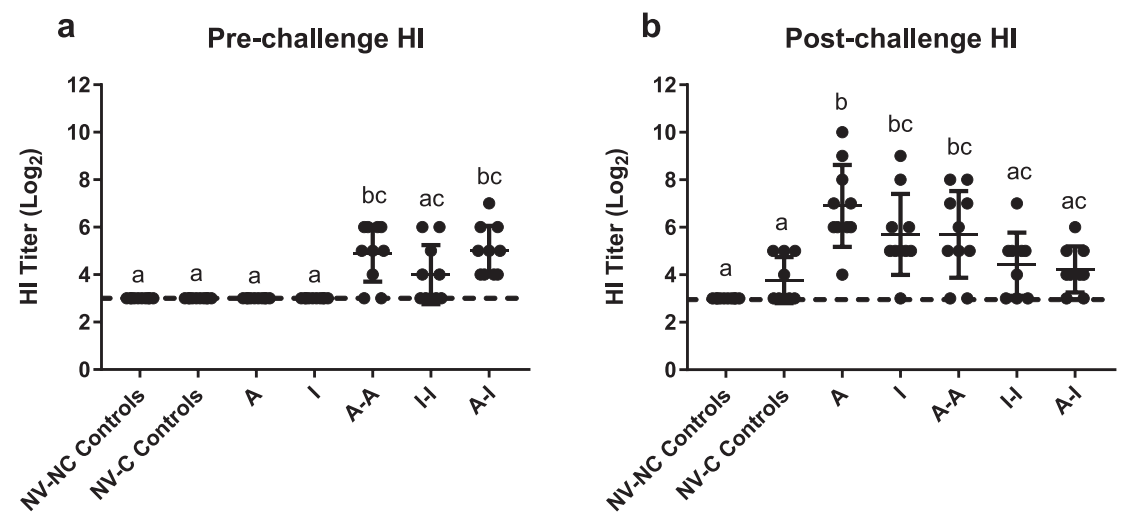

Fig. 1. Mean HI titers $\left(\log _{2}\right)$ in ducks vaccinated with a recombinant alphavirus-based replicon vaccine (A vaccine) and an inactivated reverse genetics vaccine (I vaccine) given as single vaccination or in a prime-boost regime. Serum was collected at 32 days of age, prechallenge (Fig. 1a), and $10 \mathrm{dpc}$ with A/turkey/Minnesota/12582/15 H5N2 HPAI virus (Fig. 1b) to examine the antibody responses. Bars represent standard deviation within groups. HI tests conducted using GyrF/14 virus as antigen in the HI test (virus homologous to the vaccines used). Different superscript lowercase letters denote significant difference for mean $\mathrm{HI}$ titers between groups, $P<0.05$. NV-NC $=$ nonvaccinated nonchallenged controls; $\mathrm{NV}-\mathrm{C}=$ nonvaccinated challenged controls.

Group 2 served as nonvaccinated challenged controls. The other five groups were vaccinated subcutaneously in the nape of the neck with 0.2 $\mathrm{ml}$ of the alphavirus (A) replicon vaccine $\left(10^{7}\right.$ particles per dose, as recommended by manufacturer) or of the recombinant inactivated (I) vaccine (512 HAU) at 2 days or 2 and 15 days of age (Table 1). Groups 3 and 4 were vaccinated only at 2 days of age with vaccine $A$ or vaccine I, respectively. Groups 5 and 6 additionally received a boost with the same vaccines at 15 days of age (Group 5: A-A; Group: 6 I-I). Group 7 was vaccinated at 2 days with vaccine $A$ and at 15 days with vaccine I (AI). At 32 days of age, blood samples were collected from all vaccinated ducks for serology, and all ducks were inoculated intranasally with $10^{6.0}$ EID $_{50}$ of the Tk/15 challenge HPAI virus. Ducks were observed daily for clinical signs and mortality. Oropharyngeal (OP) and cloacal (CL) swabs were collected at 3, 5, 7, and 10 days postchallenge (dpc) for determining viral shedding. At the end of the experiment $(10 \mathrm{dpc})$, blood was collected from all surviving ducks for serology, and ducks were euthanatized by injection of sodium pentobarbital $(5 \mathrm{~g} / \mathrm{ml})$. This study and associated procedures were reviewed and approved by the USNPRC Institutional Animal Care and Use Committee.

Serology. Hemagglutination inhibition (HI) tests were performed to determine antibody responses against vaccines and challenge viruses in the serum samples collected before challenge and at $10 \mathrm{dpc}$ (12). Inactivated $\mathrm{GyrF} / 14$ virus was used as $\mathrm{HI}$ antigen. $\mathrm{HI}$ titers are reported as $\log _{2}$ values, with $>3 \log _{2}$ (1:8) being the minimum titer considered as positive.

Determination of virus shedding. OP and CL swabs were collected in sterile brain heart infusion medium and kept frozen at $-70 \mathrm{C}$. Total RNA was extracted by using MagMAX ${ }^{\mathrm{TM}}-96$ AI/ND Viral RNA Isolation Kit ${ }^{\circledR}$ (Ambion, Inc., Austin, TX) following the manufacturer's instructions. Real time quantitative reverse transcription polymerase chain reactions (qRRT-PCR)targeting the influenza virus M gene (21) were conducted by using AgPath-ID One-Step RT-PCR Kit (Ambion, Inc.) and the ABI 7500 Fast Real-Time PCR system (Applied Biosystem, Carlsbad, CA). For viral quantification, a standard curve was established with viral RNA extracted from the same titrated stock of challenge virus. Results were reported as $\mathrm{EID}_{50}$ per milliliter equivalents, with the lower limit of detection being $10^{2} \mathrm{EID}_{50} / \mathrm{ml}$.

Statistical analysis. All data analyses were performed by using Prism Version 7 software (GraphPad Software Inc., San Diego, CA). One-way ANOVA with Tukey posttest was used to analyze virus titers in swabs. For statistical purposes, all OP and CL swabs from which viruses were not detected were given a numeric value of $10^{1.9} \mathrm{EID}_{50} / \mathrm{ml}$. These values were given on the basis of a detectable level of virus in these samples dependent on the methods used. Statistical significance was set at $P<$ 0.05 .

\section{RESULTS}

Clinical signs. The nonvaccinated nonchallenged birds did not show clinical signs. One duck from the nonvaccinated group challenged with the Tk/15 HPAI virus presented mild ataxia starting at $3 \mathrm{dpc}$, and a second duck was found dead at $4 \mathrm{dpc}$. The remaining ducks in this group did not show clinical signs of disease. One duck from the group vaccinated with the A vaccine showed mild ataxia starting at $4 \mathrm{dpc}$. One duck from the I-I vaccinated group and one from the A-I group had to be euthanatized at $8 \mathrm{dpc}$ because of leg problems unrelated to infection. No clinical signs were present in any of the remaining vaccinated ducks.

Serum antibody responses to vaccination and infection. Antibody responses following vaccination were tested prior to challenge and at $10 \mathrm{dpc}$ by using the inactivated $\mathrm{GyrF} / 14$ virus as antigen in the $\mathrm{HI}$ test (same HA as the vaccines used). None of the nonvaccinated ducks and ducks that received the single A or I vaccines had positive prechallenge HI titers (Fig. 1a). Also, $50 \%$ to $100 \%$ of the primeboosted vaccinated ducks developed positive prechallenge HI titers $(\geq 3 \log 2)$. Titers between these three groups were not significantly different $(P<0.01)$, but all birds vaccinated with A-I seroconverted, contrary to birds vaccinated with A-A and I-I in which 8 of 10 or 5 of 10 , respectively, seroconverted.

Following challenge, four of nine of the unvaccinated challenged ducks had positive titers $(4-5 \log 2)$ when examined at $10 \mathrm{dpc}$ (Fig. 1b). All ducks vaccinated with the A vaccine and 9 of 10 of the ducks vaccinated with the I vaccine seroconverted (titers of 4-10 $\log _{2}$ and 5-9 $\log _{2}$ respectively). In the prime-boosted vaccine groups (A-A, I-I, and A-I) 8 of 10,6 of 9, and 7 of 9 of the ducks seroconverted, respectively. Titers between these three groups were not significantly different. Although titers were also not different between groups that received the A, I, or A-A vaccines, there were significantly lower titers in the I-I and the A-I groups when compared with the A and I vaccine groups $(P<0.01)$.

Virus shedding after challenge with $\mathrm{H} 5 \mathrm{~N} 2$ clade 2.3.4.4 virus. Virus shedding was monitored by quantification of viral RNA in OP and CL samples collected at different time points after virus 
challenge (Table 2; Fig. 2). Virus replicated and was shed efficiently from the upper respiratory and intestinal tract of the nonvaccinated challenged ducks, with a mean OP titer of $5.8 \log _{10} \mathrm{EID}_{50}$ and a mean CL titer of $3.6 \log _{10}$ EID $_{50}$ at $3 \mathrm{dpc}$. Most ducks from this group were still shedding virus at $10 \mathrm{dpc}$.

In contrast, no virus shedding was detected in ducks twice vaccinated with the I-I and A-I prime-boost strategy, and only one duck from the A-A vaccine group shed low titers of virus by the OP and CL route. Although virus shedding was detected in some ducks vaccinated with the single A or I vaccines, no significant difference in virus titers was found between these groups and the groups of ducks receiving the prime-boost vaccine strategy. OP and CL virus titers for all vaccinated groups and at all time points were significantly lower than virus titers from the nonvaccinated challenge group.

On the basis of virus shed, ducks vaccinated with the I-I and A-I prime-boost strategy did not become infected. Nine out of 10 ducks vaccinated with A-A were also protected from infection; however, on the basis of serology at $10 \mathrm{dpc}$, some boost effect was observed in two ducks, indicating possible low virus replication. Most ducks vaccinated with the single A or I vaccines shed virus (eight and nine, respectively), and a boost effect on $\mathrm{HI}$ titers was observed at $10 \mathrm{dpc}$ when compared with prechallenge HI titers.

\section{DISCUSSION}

Domestic waterfowl have an important role in the maintenance of $\mathrm{H} 5 \mathrm{Nx}$ HPAI viruses. Despite control efforts, H5Nx HPAI viruses continue to circulate within various poultry populations, including domestic ducks. During the U.S. outbreak, H5N8 and H5N2 HPAI viruses were detected in backyard waterfowl (28) and H5N8 HPAI viruses in commercial duck facilities (19). Other clade 2.3.4.4 H5Nx HPAI viruses have also caused outbreaks in domestic ducks in several countries around the world $(2,10)$. Many Gs/GD lineage $\mathrm{H} 5 \mathrm{~N} 1 \mathrm{HPAI}$ viruses and, recently, clade 2.3.4.4 Gs/GD-derived $\mathrm{H} 5 \mathrm{Nx}$ viruses have caused disease and death in wild and domestic ducks $(2,6,10,13,15,18,19,23)$, and both sick and asymptomaticinfected ducks shed high amounts of virus into the environment, favoring transmission and potential outbreaks in commercial poultry. In this study, we evaluated the efficacy of a recombinant alphavirus-based replicon vaccine (A vaccine) and an adjuvanted and inactivated reverse genetics vaccine (I vaccine) in protecting Pekin ducks against challenge with a H5N2 HPAI clade 2.3.4.4 virus.

All nonvaccinated ducks challenged with the Tk/15 HPAI virus became infected. The virus replicated to high titers in most ducks, and mild neurologic signs or mortality was observed in two ducks. This same virus also caused low mortality and was shed in high titers in mallards and had a similar high infectivity as the U.S. index H5N2 and H5N8 HPAI viruses and a 2005 H5N1 HPAI Gs/GD lineage virus, with all viruses transmitting efficiently to direct contacts (1). We demonstrated that both vaccines reduced significantly, or prevented, virus shedding after challenge in young ducks. As expected, the best protection occurred with the primeboost strategy, which protected most of the ducks against infection. Antibody titers were not predictive of protection in ducks that received the single vaccines, with prechallenge $\mathrm{HI}$ antibody titers being undetectable. Boosting with either the same (I-I or A-A) or a different vaccine (A-I) strategy significantly increased HI titers. Either way, single or prime-boost vaccination reduced significantly 

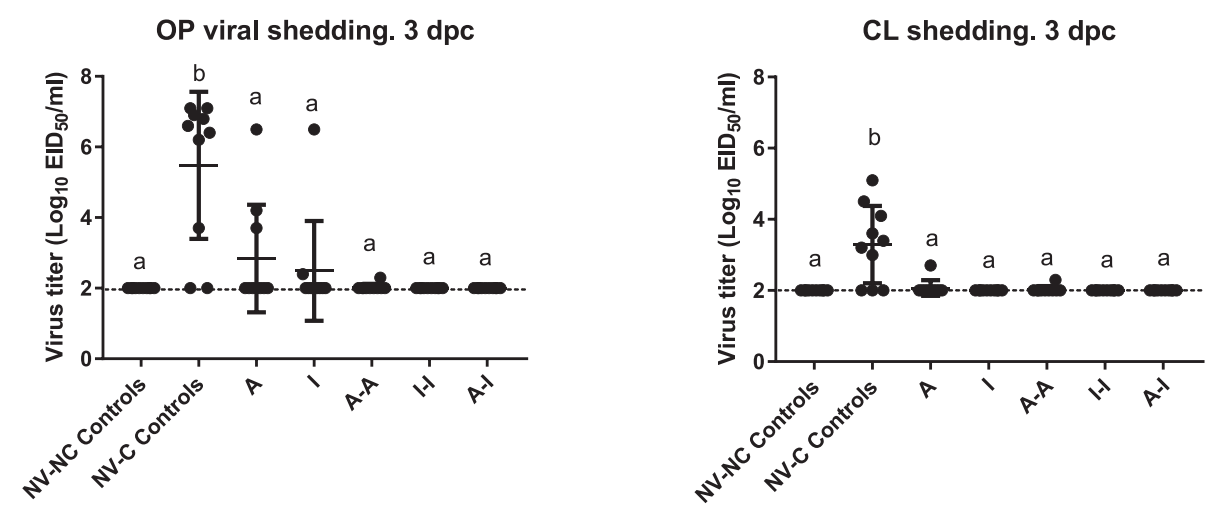

OP viral shedding. $5 \mathrm{dpc}$

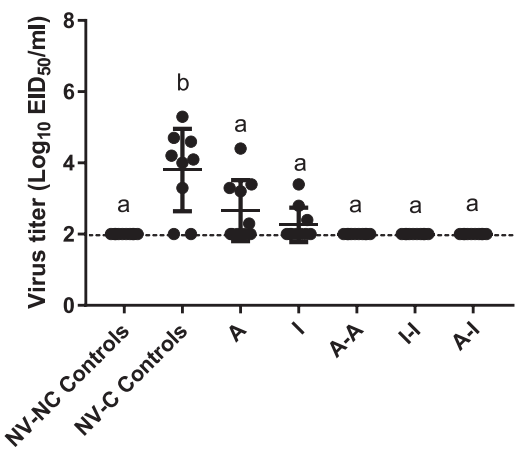

OP viral shedding. $7 \mathrm{dpc}$

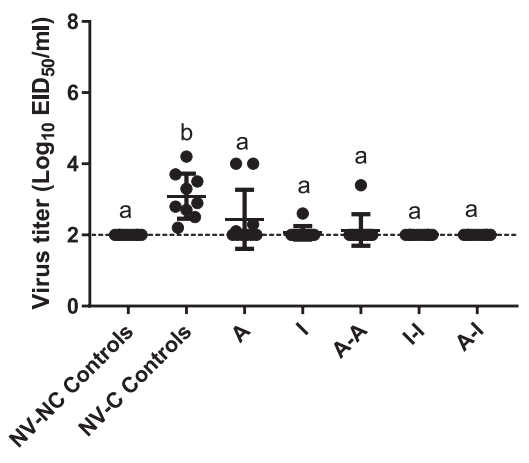

OP viral shedding. $10 \mathrm{dpc}$

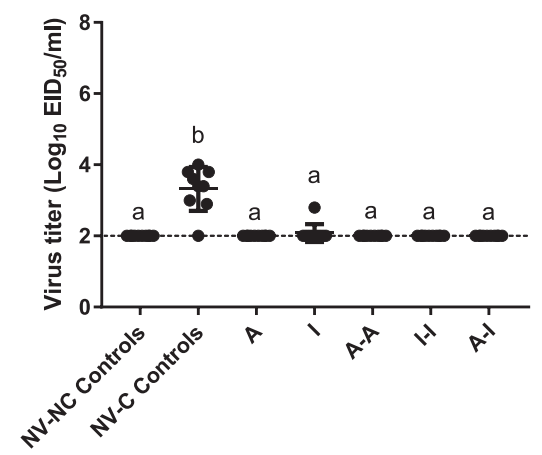

CL shedding. 5 dpc

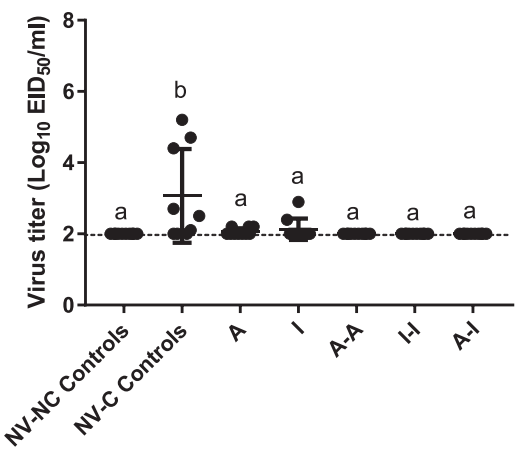

CL shedding. 7 dpc

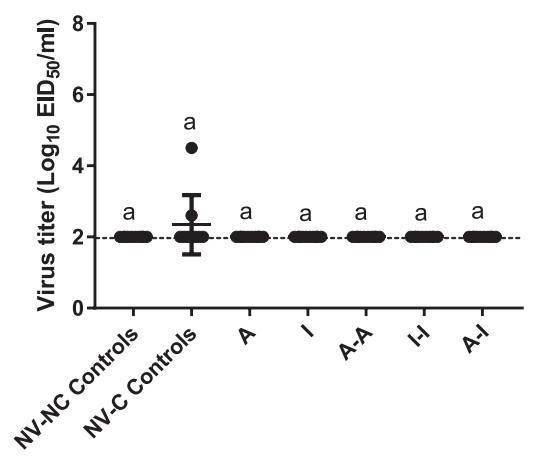

CL shedding. $10 \mathrm{dpc}$

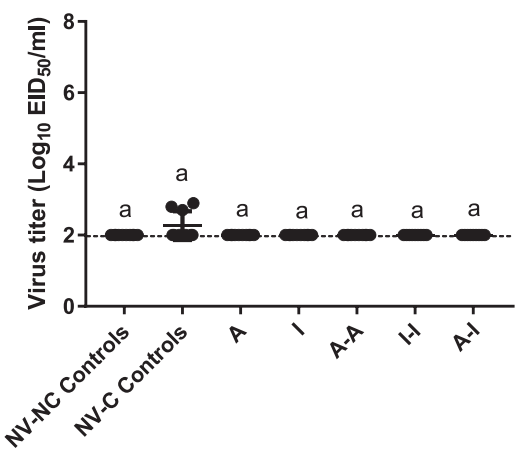

Fig. 2. Virus shedding. Swab samples were taken from all ducks at each day after challenge with the A/turkey/Minnesota/12582/15 H5N2 HPAI virus; $\log _{10}$ EID $_{50}$ equivalents were determined by qRRT-PCR; OP = oropharyngeal; $\mathrm{CL}=$ cloacal swabs; NV-NC $=$ nonvaccinated nonchallenged controls; NV-C $=$ nonvaccinated challenged controls. Different superscript lowercase letters denote significant difference for mean viral titers between groups, $P<0.05$. For statistical purposes, all swabs without viral RNA detection were given a numeric value of 2 log 10 EID 50 equivalents. 
virus shedding, which would most likely limit virus transmission. It is commonly observed that viral-vectored vaccines produce low levels of HI antibody but often provide good protection from challenge in chickens (Gallus gallus domesticus) (24). This protection is thought to be from the combined cell-mediated and humoral immunity. Inactivated vaccines generally produce high levels of $\mathrm{HI}$ antibody in chickens but are not thought to produce protective levels of cytotoxic T-cell immunity. Therefore, the protection observed from the single I vaccine, which did not produce detectable HI antibody, is currently unexplainable. Assays that better correlate the immune response to vaccination with the outcomes of virus challenge are needed for ducks. This study confirms results from earlier studies that show that the antibody response in Pekin ducks is lower than what is observed in chickens given the same vaccines. To our knowledge, this is the first study on the use of the alphavirus vaccine system in ducks, and this challenge suggests that it provides at least similar protection to inactivated vaccines. Because this was a study of short duration, we can only speculate if differences in the two types of vaccine would become more apparent over time.

The protection observed with the vaccines used in this study can be attributed to the vaccines expressing HA proteins homologous to the challenge virus (99\% similar). Other studies with $\mathrm{H} 5 \mathrm{~N} 1$ viruses showed that when the vaccine and the challenge virus belong to the same $\mathrm{H} 5$ subtype and are expected to have high HA homology, vaccinated ducks were well protected against challenge virus (14). Genetically more distant vaccines also protected ducks against infection with $\mathrm{H} 5 \mathrm{~N} 1$ viruses (14), but previous studies in chickens demonstrated that antigenically matched vaccines provided superior protection in a single vaccination strategy, as measured by virus shedding (4).

The HA of the vaccines used in this study had greater than 98.2\% sequence similarity to other Gs/GD H5Nx clade 2.3.4.4A viruses, but similarity was lower compared with the HA of more current viruses from clade 2.3.4.4 B, C, and D $(<96.8 \%$; Supplemental Data S1 and Supplemental Fig. S1). A study examining the antigenic diversity of Asian H5 HPAI viruses also found that the antigenicity of clade 2.3.4.4 viruses differed slightly among Groups A, B, and C (11). Although there is a correlation between genetic and antigenic distance, specific genetic differences of as little as a single amino acid can lead to a substantial antigenic differences (20). A study by Peeters et al. examining protection provided by vaccines against heterologous $\mathrm{H} 5 \mathrm{~N} 1$ challenge viruses in chickens found that cross protection correlated better with genetic variation in selected antigenically relevant residues than in the complete HA1 protein (17). In any case, genetic and antigenic differences might affect the efficacy of the vaccines examined in this study in protecting ducks against infection with more recent $\mathrm{H} 5 \mathrm{Nx}$ clade 2.3.4.4 viruses.

Results from field and laboratory evaluation of vaccines against H5N1 HPAI in ducks indicates that factors, such as challenge virus, duck species, vaccination protocols, and proper use of vaccines, may significantly influence the outcome of the vaccination program. Other factors, including the role of maternally derived antibodies and coinfection with other pathogens, remain to be determined in ducks. Better matching of vaccines with circulating viruses, optimized vaccines, and vaccination programs should improve the results of influenza immunization in ducks. Greater attention to duck vaccination has to be considered if eradication of $\mathrm{H} 5 \mathrm{Nx} \mathrm{HPAI}$ is the ultimate goal.

\section{REFERENCES}

1. DeJesus, E., M. Costa-Hurtado, D. Smith, D. H. Lee, E. Spackman, D. R. Kapczynski, M. K. Torchetti, M. L. Killian, D. L. Suarez, D. E. Swayne, and M. J. Pantin-Jackwood. Changes in adaptation of H5N2 highly pathogenic avian influenza $\mathrm{H} 5$ clade 2.3.4.4 viruses in chickens and mallards. Virology 499:52-64. 2016.

2. Food and Agricultural Organization of the United Nations. Animal Production and Health. H5N8 HPAI global situation update [Internet]. [cited 2018 May 9] Available from: http://www.fao.org/ag/againfo/ programmes/en/empres/H5N8/situation_update.html

3. Ip, H. S., M. K. Torchetti, R. Crespo, P. Kohrs, P. DeBruyn, K. G. Mansfield, T. Baszler, L. Badcoe, B. Bodenstein, V. Shearn-Bochsler, M. L. Killian, J. C. Pedersen, N. Hines, T. Gidlewski, T. DeLiberto, and J. M. Sleeman. Novel Eurasian highly pathogenic avian influenza A H5 viruses in wild birds, Washington, USA, 2014. Emerg. Infect. Dis. 21:886-890. 2015.

4. Kapczynski, D. R., M. J. Pantin-Jackwood, E. Spackman, K. Chrzastek, D. L. Suarez, and D. E. Swayne. Homologous and heterologous antigenic matched vaccines containing different $\mathrm{H} 5$ hemagglutinins provide variable protection of chickens from the 2014 U.S. H5N8 and H5N2 clade 2.3.4.4 highly pathogenic avian influenza viruses. Vaccine 35:6345-6353. 2017.

5. Kapczynski, D. R., M. J. Sylte, M. L. Killian, M. K. Torchetti, K. Chrzastek, and D. L. Suarez. Protection of commercial turkeys following inactivated or recombinant $\mathrm{H} 5$ vaccine application against the 2015 U.S. $\mathrm{H} 5 \mathrm{~N} 2$ clade 2.3.4.4 highly pathogenic avian influenza virus. Vet. Immunol. Immunopathol. 191:74-79. 2017.

6. Lee, D. H., J. H. Kwon, J. Y. Noh, J. K. Park, S. S. Yuk, T. O. Erdene-Ochir, J. B. Lee, S. Y. Park, I. S. Choi, S. W. Lee, and C. S. Song. Pathogenicity of the Korean H5N8 highly pathogenic avian influenza virus in commercial domestic poultry species. Avian Pathol. 45:208-211. 2016.

7. Lee, D. H., M. K. Torchetti, M. L. Killian, T. J. DeLiberto, and D. E. Swayne. Reoccurrence of avian influenza $\mathrm{A}(\mathrm{H} 5 \mathrm{~N} 2)$ virus clade 2.3.4.4 in wild birds, Alaska, USA, 2016. Emerg. Infect. Dis. 23:365-367. 2017.

8. Lee, D. H., M. K. Torchetti, K. Winker, H. S. Ip, C. S. Song, and D. E. Swayne. Intercontinental spread of Asian-origin H5N8 to North America through Beringia by migratory birds. J. Virol. 89:6521-6524. 2015.

9. Mogler, M. A., and K. I. Kamrud. RNA-based viral vectors. Expert. Rev. Vaccines 14:283-312. 2015.

10. Nunez, A., S. M. Brookes, S. M. Reid, C. Garcia-Rueda, D. J. Hicks, J. M. Seekings, Y. I. Spencer, and I. H. Brown. Highly pathogenic avian influenza $\mathrm{H} 5 \mathrm{~N} 8$ clade 2.3.4.4 virus: equivocal pathogenicity and implications for surveillance following natural infection in breeder ducks in the United Kingdom. Transbound. Emerg. Dis. 63:5-9. 2016.

11. Ohkawara, A., M. Okamatsu, M. Ozawa, D. H. Chu, L. T. Nguyen, T. Hiono, K. Matsuno, H. Kida, and Y. Sakoda. Antigenic diversity of $\mathrm{H} 5$ highly pathogenic avian influenza viruses of clade 2.3.4.4 isolated in Asia. Microbiol. Immunol. 61:149-158. 2017.

12. [OIE] World Organisation for Animal Health. Chapter 2.3.4. Avian influenza. In: Manual for diagnostic tests and vaccines for terrestrial animals [Internet]. May 2015 [; cited 2018 May 9]. Available from: http:// www.oie.int/fileadmin/Home/eng/Health_standards/tahm/2.03.04_AI.pdf. 2015

13. Pantin-Jackwood, M. J., M. Costa-Hurtado, K. Bertran, E. DeJesus, D. Smith, and D. E. Swayne. Infectivity, transmission and pathogenicity of $\mathrm{H} 5$ highly pathogenic avian influenza clade 2.3.4.4 (H5N8 and $\mathrm{H} 5 \mathrm{~N} 2$ ) United States index viruses in Pekin ducks and Chinese geese. Vet. Res. 48:33. 2017.

14. Pantin-Jackwood, M. J., and D. L. Suarez. Vaccination of domestic ducks against H5N1 HPAI: a review. Virus Res. 178:21-34. 2013.

15. Pantin-Jackwood, M. J., and D. E. Swayne. Pathogenesis and pathobiology of avian influenza virus infection in birds. Rev. Sci. Tech. 28:113-136. 2009.

16. Pasick, J., Y. Berhane, T. Joseph, V. Bowes, T. Hisanaga, K. Handel, and S. Alexandersen. Reassortant highly pathogenic influenza A $\mathrm{H} 5 \mathrm{~N} 2$ virus containing gene segments related to Eurasian $\mathrm{H} 5 \mathrm{~N} 8$ in British Columbia, Canada, 2014. Sci. Rep. 5:9484. 2015.

17. Peeters, B., S. Reemers, J. Dortmans, E. de Vries, M. de Jong, S. van de Zande, P. J. M. Rottier, and C. A. M. de Haan. Genetic versus 
antigenic differences among highly pathogenic $\mathrm{H} 5 \mathrm{~N} 1$ avian influenza A viruses: consequences for vaccine strain selection. Virology 503:83-93. 2017.

18. Pohlmann, A., E. Starick, T. Harder, D. Hoper, A. Globig, C. Staubach, K. Dietze, C. Grund, G. Strebelow, R. G. Ulrich, J. Schinkothe, J. P. Teifke, F. J. Conraths, T. C. Mettenleiter, and M. Beer. Outbreaks among wild birds and domestic poultry caused by reassorted influenza A(H5N8) clade 2.3.4.4 viruses, Germany, 2016. Emerg. Infect. Dis. 23:633-636. 2017.

19. Shivaprasad H, S. S., S. Carnaccini, B. Crossley, G. Senties-Cue, and R. Chin. An overview of outbreaks of LPAI and HPAI H5N8 in commercial poultry in California. In: Proc. 65th Western Poultry Disease Conference, Vancouver, British Columbia, Canada. p. 261. Apr. 24-27, 2016.

20. Smith, D. J., A. S. Lapedes, J. C. de Jong, T. M. Bestebroer, G. F. Rimmelzwaan, A. D. Osterhaus, and R. A. Fouchier. Mapping the antigenic and genetic evolution of influenza virus. Science 305:371-376. 2004.

21. Spackman, E., D. A. Senne, T. J. Myers, L. L. Bulaga, L. P. Garber, M. L. Perdue, K. Lohman, L. T. Daum, and D. L. Suarez. Development of a real-time reverse transcriptase PCR assay for type A influenza virus and the avian $\mathrm{H} 5$ and $\mathrm{H} 7$ hemagglutinin subtypes. J. Clin. Microbiol. 40:32563260. 2002.

22. Stoute, S., R. Chin, B. Crossley, C. Gabriel Senties-Cue, A. Bickford, M. Pantin-Jackwood, R. Breitmeyer, A. Jones, S. Carnaccini, and H. L. Shivaprasad. Highly pathogenic Eurasian H5N8 avian influenza outbreaks in two commercial poultry flocks in California. Avian Dis. 60:688-693. 2016.

23. Stoute, S., B. Crossley, and H. L. Shivaprasad. Study of an outbreak of highly pathogenic avian influenza H5N8 in commercial Pekin ducks (Anas platyrhynchos domesticus) in California. Avian Dis. 62:101-108. 2018.

24. Suarez, D. L., and M. J. Pantin-Jackwood. Recombinant viralvectored vaccines for the control of avian influenza in poultry. Vet. Microbiol. 206:144-151. 2017.

25. Swayne, D. E., R. E. Hill, and J. Clifford. Safe application of regionalization for trade in poultry and poultry products during highly pathogenic avian influenza outbreaks in the USA. Avian Pathol. 46:125130. 2017.

26. Swayne, D. E., and D. R. Kapzcynski. Vaccines, vaccination, and immunology for avian influenza viruses in poultry. In: Avian influenza. D. E. Swayne, ed. Blackwell Publishing, Ames, IA. pp. 407-451. 2008.
27. U.S. Department of Agriculture, Animal and Plant Health Inspection Service. Epidemiologic and other analyses of HPAI-affected poultry flocks: report [Internet]. Published June 15, 2015; cited 2018 May 9. Available from: https://www.aphis.usda.gov/animal_health/animal_dis_ spec/poultry/downloads/Epidemiologic-Analysis-June-15-2015.pdf

28. U.S. Department of Agriculture, Animal and Plant Health Inspection Service. Highly pathogenic avian influenza infected premises 2014-2015 [Internet]. 2015 [cited 2018 May 9]. Available from: https:// www.aphis.usda.gov/animal_health/animal_dis_spec/poultry/downloads/ hpai-positive-premises-2014-2015. pdf

29. U.S. Department of Agriculture, Animal and Plant Health Inspection Service. Animal disease information, avian influenza, HPAI 2014/2015 confirmed detections [Internet]. 2015 [; cited 2018 May 9]. Available from: https://www.aphis.usda.gov/aphis/ourfocus/animalhealth/ animal-disease-information/avian-influenza-disease/sa_detections_by_states/ hpai-2014-2015-confirmed-detections

30. Vander Veen, R. L., D. L. Harris, and K. I. Kamrud. Alphavirus replicon vaccines. Anim. Health Res. Rev. 13:1-9. 2012.

31. Vander Veen, R. L., A. T. Loynachan, M. A. Mogler, B. J. Russell, D. L. Harris, and K. I. Kamrud. Safety, immunogenicity, and efficacy of an alphavirus replicon-based swine influenza virus hemagglutinin vaccine. Vaccine 30:1944-1950. 2012.

32. Verhagen, J. H., S. Herfst, and R. A. Fouchier. Infectious disease. How a virus travels the world. Science 347:616-617. 2015.

\section{ACKNOWLEDGMENTS}

We appreciate the technical assistance provided by Nikolai Lee and the animal care provided by Bill Gagnon, Keith Crawford, Gerald Damron, and Roger Brock in conducting these studies. This research was supported by the U.S Department of Agriculture (USDA) Agricultural Research Service Project 6040-32000-066$00 \mathrm{D}$. Mention of trade names or commercial products in this publication is solely for the purpose of providing specific information and does not imply recommendation or endorsement by the USDA. USDA is an equal opportunity provider and employer. 